Volume 10, Issue 6, November-December 2019, pp. 191-197, Article ID: IJM_10_06_019

Available online at http://iaeme.com/Home/issue/IJM?Volume $=10 \&$ Issue $=6$

Journal Impact Factor (2019): 9.6780 (Calculated by GISI) www.jifactor.com

ISSN Print: 0976-6502 and ISSN Online: 0976-6510

\title{
EFFECT OF COMMUNICATION, AND EMPLOYMENT STANDARDS DEVELOPMENT EMPLOYEE SATISFACTION
}

\author{
Syaifuddin \\ Universitas Prima Indonesia, Medan, Indonesia \\ Fajar Rezeki Ananda Lubis \\ Universitas Prima Indonesia, Medan, Indonesia \\ Yusniar Lubis \\ Universitas Medan Area, Indonesia
}

\begin{abstract}
This study aimed to determine the effect of communication, labor standards and the empowerment of job satisfaction in the Business Unit Dolok harvest Ilir PTPN IV. This research was conducted in August 2019. The number of samples in this study as many as 31 people. The independent variable in this study consisted of communication (X1), work standards (X2) and empowerment (X3), while the dependent variable is job satisfaction (Y). Analysis of data using multiple regression analysis using SPSS. The results showed that communication, employment standards and labor empowerment simultaneously significant effect on employee job satisfaction. Partially that communication, employment standards and labor empowerment significant effect on employee job satisfaction.
\end{abstract}

Keywords: Cooperative Banking, Financial Efficacy, District Central Cooperative Banks, CAMEL Model.

Cite this Article: Syaifuddin, Fajar Rezeki Ananda Lubis, Yusniar Lubis, Effect of Communication, and Employment Standards Development Employee Satisfaction, International Journal of Management (IJM), 10 (6), 2019, pp. 191-197.

http://iaeme.com/Home/issue/IJM?Volume $=10 \&$ Issue $=6$

\section{INTRODUCTION}

Job satisfaction is one form of one's feelings toward his work, the work situation and relations with colleagues. Therefore, job satisfaction is something that is important to have an employee, in interacting with its environment so that responsibility given by the company can be carried out properly in accordance with the objectives of the company. Job satisfaction is considered important in the scope of the organization because it has a great influence on the productivity of the organization, either directly or indirectly. 
Through good communication, an organization can run smoothly and successfully, and vice versa. Lack or absence of organizational communication can result in jams and messy a company. Communication is very important in human life. Not only used as a dispenser communication messages, ideas, ideas or pieces of his mind, but communication is used as a tool to influence others or as the perception and interaction tools to achieve various objectives of individuals, companies and community groups.

Employee to perform an act or the work comes from the interaction between the factors motif with the environmental situation at hand and can be upgraded via a communication relationship good organization. Through communication, a leader or head office always pay attention to and foster good relationships to manage employees in the work.

Besides communication, job satisfaction is also influenced by the presence of employee empowerment given by treating employees as people who have a sense of great responsibility, were invited to participate in decision making, not only regarding employment and job title but also includes a variety of organizational life in general, do the job attractive, their freedom of action plan, setting goals, organizing the work completion schedule, determine their own way of solving problems, developing potential opportunities into actual effective operational capabilities, thus increasing performance. Empowerment increase confidence in doing something, which at the time had not previously been believed possible for the employees of the organization,

According Greasly and Bryman (2008: 5), the empowerment program designed to delegate authority, authorized by superiors to their subordinates and to share responsibility with them. All this can improve the status and recognition of employees who are empowered. Employees prepare their mindset to do the job and try to do our best to achieve individual goals, tujan team, and organizational objectives.

Standard performance by Wibowo (2012: 74) is a statement about the situation that occurs when a job done effectively. The performance standards related to the image of the activities carried out employees to complete the job according to the company's goals. Required performance standards to guide the behavior of employees in order to implement the standards that have been made. Defined goals leader with written evidence submitted to the employee along with the steps that must be done.

The performance standards are an important part of the planning process performance management. Determining and implementing the performance standards should involve all personnel who will join and work together to achieve corporate objectives. The Performance Standards describe how the work carried out the expectations and company leaders to its employees. The performance standards make the job can be done effectively and efficiency. Assessment of the performance can be used as a benchmark by the company.

Employee satisfaction is also influenced by employee empowerment. According Greasly and Bryaman (2008: 5), the empowerment program designed to delegate authority, authorized by superiors to their subordinates and to share responsibility with them. All this can improve the status and recognition of employees who are empowered. Employees preparing the mindset to do the job and try to do our best to achieve individual goals, team goals and objectives of the organization.

According to Robbins (2013: 10), job satisfaction refers to the individual's attitude in general towards his job. A person with a high level of job satisfaction has a positive attitude towards work, while someone who is not satisfied with his work having a negative attitude toward his work.

This study aimed to determine the effect of communication, labor standards and the empowerment of job satisfaction to improve the employee's Business Unit Ilir Dolok PTPN IV. 


\section{RESEARCH METHODOLOGY}

This research was conducted at the Business Unit Ilir Dolok PTPN IV is one of the palm oil plantation PTPN IV. This study was conducted in August 2019.

The study population was all employees of the harvest in the Business Unit Ilir Dolok PTPN IV, as many as 304 people. The sample was determined at $10 \%$ of the population, or as many as 31 people. Data collected through questionnaires.

The research variables consist of independent variables, namelycommunication (X1), work standards (X2) and empowerment (X3), while the dependent variable (Y) is employee satisfaction. Testing the hypothesis used multiple linear regression analysis, then dilajutkan by $\mathrm{F}$ test and $\mathrm{t}$ test. F-test was used for analysis simultaneously, with the provision that if $\mathrm{F}$ count $>$ $\mathrm{F}$ table then $\mathrm{H} 0$ rejected and $\mathrm{H} 1$ accepted, otherwise if Fhitung $\leq$ Ftabel then $\mathrm{H} 0$ and $\mathrm{H} 1$ rejected. The t-test was used for analysis partially, with the provision that if $\mathrm{t}>\mathrm{t}$ table then $\mathrm{H} 0$ rejected and $\mathrm{H} 1$ accepted, otherwise if $\mathrm{t} \leq \mathrm{t}$ table then $\mathrm{H} 0$ and $\mathrm{H} 1$ rejected.

\section{RESULTS}

\subsection{Simultaneous Test}

Influence communication variables, labor standards, and the empowerment of employee job satisfaction variables can be seen in Table 1 below.

Table 1. Simultaneous Test Results

\begin{tabular}{|ll|c|c|c|c|c|}
\hline \multicolumn{1}{|c|}{ Model } & Sum of Squares & df & mean Square & F & Sig. \\
\hline 1 & Regression & 306768 & 3 & 102256 & 22428 & $.000 \mathrm{a}$ \\
& residual & 123103 & 27 & 4,559 & & \\
& Total & 429871 & 30 & & & \\
\hline
\end{tabular}

a. Predictors: (Constant), Empowerment, Communication, Standar_kerja

b. Dependent Variable: Kepuasan_kerja

From Table 1 Fhitung 22428 values obtained with significance 0.00 , then H0 rejected and $\mathrm{H} 1$ accepted, means of communication variables, labor standards, and the empowerment of a significant effect on job satisfaction of employees in the Business Unit Ilir Dolok PTPN IV.

The coefficient of determination (R2) is known to the influence of changes in variablescommunication, labor standards, and empowering employee job satisfaction variables change in the Business Unit Ilir Dolok PTPN IV, are presented in Table 2.

Table 2. Coefficient of Determination

Model Summary

\begin{tabular}{|c|c|c|c|c|}
\hline Model & R & R Square & $\begin{array}{c}\text { adjusted R } \\
\text { Square }\end{array}$ & $\begin{array}{c}\text { Std. Error of } \\
\text { the Estimate }\end{array}$ \\
\hline 1 & $.845 \mathrm{a}$ & .714 & .682 & 2.13527 \\
\hline
\end{tabular}

a. Predictors: (Constant), Empowerment, Communication, Standar_kerja

The coefficient of determination (Adjusted R Square) of 0.682 means that the change in job satisfaction of employees in the Business Unit Ilir Dolok PTPN IV can be explained by changes in communication, labor standards, and the empowerment of $68.2 \%$. While the rest of $31.8 \%$ is influenced by other variables that are not analyzed in this study. 


\subsection{Partial Test}

Test variables influence communication, labor standards, and empowerment can be partially seen in Table 3.

Table 3. Partial Test Results

Coefficients

\begin{tabular}{|c|c|c|c|c|c|c|}
\hline & \multirow[b]{2}{*}{ Model } & \multicolumn{2}{|c|}{$\begin{array}{c}\text { Coefficients } \\
\text { unstandardized }\end{array}$} & \multirow{2}{*}{$\begin{array}{c}\begin{array}{c}\text { standardized } \\
\text { Coefficients }\end{array} \\
\text { beta }\end{array}$} & \multirow[b]{2}{*}{$\mathbf{t}$} & \multirow[b]{2}{*}{ Sig. } \\
\hline & & B & Std. Error & & & \\
\hline \multirow[t]{4}{*}{1} & (Constant) & 1,116 & 2,639 & & .423 & .676 \\
\hline & Communication & .326 & .123 & .281 & 2644 & .013 \\
\hline & Standar_kerja & .602 & .272 & .347 & 2,216 & .035 \\
\hline & empowerment & 366 & .132 & 441 & 2,768 & .010 \\
\hline
\end{tabular}

a. Dependent Variable: Kepuasan_kerja

Based on the results obtained by the equation regression:

$\mathrm{Y}=1.116+0.326+0.602 \mathrm{X} 1+0.366 \mathrm{X} 2 \mathrm{X} 3$

Based on Table 3, the partial effect of variable communication (X1) obtained by tcount amounted to 2,644, with a significance of 0.013 , then $\mathrm{H} 0$ rejected and $\mathrm{H} 1$ accepted, which means that the communication variables positive and significant impact on job satisfaction of employees in the Business Unit Dolok Ilir PTPN IV, This means that if the communication the better the job satisfaction of employees in the Business Unit Ilir Dolok PTPN IV also will increase.

The partial effect of variable working standards (X2) obtained by tcount of 2.216 , with a significance of 0.035 , then $\mathrm{H} 0$ rejected and $\mathrm{H} 1$ accepted, which means that the standard variable labor and significant positive effect on employee job satisfaction in the Business Unit Ilir Dolok PTPN IV. This means that if the standard of work the better the job satisfaction of employees in the Business Unit Ilir Dolok PTPN IV also will increase.

The partial effect of variable empowerment (X3) obtained by tcount of 2.768, with a significance of 0.010 , then $\mathrm{H} 0$ rejected and $\mathrm{H} 1$ accepted, which means that the variable empowerment and significant positive effect on employee job satisfaction in the Business Unit Ilir Dolok PTPN IV. This means that if the empowerment, the better the job satisfaction of employees in the Business Unit Ilir Dolok PTPN IV also will increase

The amount of the partial effect of each variable can be seen from the partial coefficients, as follows:

Table 4. Coefficient of Determination

\begin{tabular}{|c|c|c|c|c|}
\hline \multicolumn{5}{|c|}{ Coefficients } \\
\hline & \multirow[b]{2}{*}{ Model } & \multicolumn{3}{|c|}{ correlations } \\
\hline & & Zero-order & Partial & part \\
\hline \multirow[t]{3}{*}{1} & Communication & .439 & .454 & .272 \\
\hline & Standar_kerja & .722 & .392 & .228 \\
\hline & empowerment & .770 & .470 & .285 \\
\hline
\end{tabular}

a. Dependent Variable: Kepuasan_kerja 
Based on the partial deternimasi coefficient, it is known that the effect of the partial communication on employee job satisfaction is the $20.61 \%(0.4542)$, the effect of the partial work standards by $15.37 \%(0.3922)$, the effect of a partial empowerment of $2209 \%(0.472)$. Thus empowering more dominant influence onjob satisfaction in the Business Unit Ilir Dolok PTPN IV

\section{DISCUSSION}

$\mathrm{T}$ test results showed thatcommunication significantly influence employee satisfaction. Communication is an important factor in the effort to achieve organizational goals. Communication can express desires, needs, and also what is meant by someone. To finish a job that the employee has been difficult to resolve, then it can dikomukasikan with superiors, with receives information from subordinates, to establish horizontal communication, establish communication across channels and informal communications are likely to contain confidential report about the people and events that do not flow through companies that formal channels. The results of this study support previous research conducted by Novieka and Prasetya (2018) that the formal communication channels affect the job satisfaction of employees at PT PLN Persero Pasuruan Area. Research Mariati (2017) also support this research which concluded that organizational communication is the message indicator on employee job satisfaction.

$\mathrm{T}$ test results showed thatlabor standards and significant positive effect on employee job satisfaction. Their work standards as a reference guide for employees to do the job. With the standard becomes easier for employees in completing their work due to the whole set of work practices have terprosedur recording in a standard work. With so employees do not contingent with a co-worker to finish the job and can complete the work in accordance with the specified time. By not contingent employees will feel more able to be his work and lead to the satisfaction of oneself due to complete its work by using labor standards as a guideline it works.

$\mathrm{T}$ test results showed thatempowering positive and significant effect on employee job satisfaction. Employee empowerment can be done by providing the opportunity for employees to identify the problems that are happening. In this case the company is still execute it poorly, because there are many yarawan were not given the opportunity to identify the problems that occur. This will lead to low employee satisfaction. Employee empowerment can be created by the lack of mutual trust organsiasi members will create favorable conditions for the exchange of information and advice without fear. In this case the company has done a good job, although there is still a couple of employees who are afraid to exchange information. Lack of mutual trust between the employees of the company will increasingly make them feel comfortable in carrying out their work. Employee empowerment can be created to generate the confidence of employees with respect to the capabilities of the employees of the included actions that give rise to confidence. The higher the confidence will increase employees' ability to perform the job. Companies award given to the implementation of the work of employees will further increase employee job satisfaction. The higher the confidence will increase employees' ability to perform the job. Companies award given to the implementation of the work of employees will further increase employee job satisfaction. The higher the confidence will increase employees' ability to perform the job. Companies award given to the implementation of the work of employees will further increase employee job satisfaction.

Empowerment is the process of granting authority or autonomy to its employees in terms of taking a decision, take the solution to the problem, and determine for themselves how they are to finish the job. The results also support previous research conducted by Miser et al. (2011) showed that the empowerment of a significant effect on job satisfaction. The study also supports research Javed et al (2014); Waqas et al (2014) that the empowerment of employees are also leading to higher levels of job satisfaction. Employees who are empowered to solve everyday 
problems in the company feel appreciated. It creates a feeling of satisfaction for the employee or in other words empowerment increases employee job satisfaction.

F test results indicate that simultaneous communication, labor standards and empowerment have a significant effect on employee job satisfaction. In an effort to improve employee job satisfaction required communication within the organization. This communication requires qualified human resources, so that the standard required in accordance with the needs of the organization's work that can be done by hiring employees in accordance with the required qualifications or training to existing employees. Good working standards will produce a qualified employee who can run the information systems applied in the company.

\section{CONCLUSIONS AND RECOMMENDATIONS}

\subsection{Conclusion}

1. Simultaneously communication, employment standards and labor empowerment simultaneously significant effect on employee job satisfaction.

2. Partially indicate that communication, employment standards and labor empowerment significant effect on employee job satisfaction.

3. variables empowerment has a more dominant influence on employee job satisfaction compared with the communication and work standards.

\subsection{Suggestion}

1. The leadership of the company needs improve communication and better working standards, because of its influence on job satisfaction are low.

2. It is suggested to increasingly empower employees, so that will increase job satisfaction which will further increase employee productivity.

\section{REFERENCES}

[1] Achmad S. Ruky, Performance Management System (Performance Management System) Practical Guide To Designing and Achieving Performance Prima. Jakarta: Gramedia Pustaka Utama, 2011

[2] Arifin, A., D. Hamid and MS Hakam, Effect of Empowerment and Motivation on Employee Performance(Study on Employee CV. Catur Manunggal Perkasa).Journal of Business Administration (JAB)| Vol. 8 No. 2, 2014, pp 1-8.

[3] Darmayanti, Yayan, Effect of Work Environment and Standaer Operating Procedure of the Supervisory Employee Productivity Sukacinta carriages Affairs (PUG SCT) PT. Kereta Api Indonesia (Persero) Lahat. Journal of Economics and Business Education (JPEB) Vol.5 (1), 2017, pp 63-72.

[4] Greasly, K. Bryman, A. Pric, A. Naismith, Soetanto N., R, Understanding From On Employee Empowerment Perspective. Team Performance Management, Vol. 14, No. 1/2, 2008, p. 39-55.

[5] Irmaputri, AA, Qualitative Study: Empowering Employees Creative Business Company. Thesis. Yogyakarta: Faculty of Economics, Univeritas Sanata Dharma, 2017

[6] Javed, M., Balouch, R., and Hassan, F.,Determinants of Job Satisfaction and its Impact on Employee Performance and Turnover Intentions. International Journal of Learning and Development, Vol. 4 (2), 2014, pp 120-140.

[7] T. Suhasini and Kalpana Koneru, A Study on Employee Engagement Driving Factors and their Impact Over Employee Satisfaction - An Empirical Evidence from Indian IT Industry, International Journal of Mechanical Engineering and Technology 9(4), 2018, pp. 725-732. 
[8] Juniantara IW, Effect of Motivation and Satisfaction KerjaTerhadap Cooperative Employee Performance In Denpasar. E-Journal of Economics and Business, University of Udayana 4:09 (2015), 2015, pp 611- 628.

[9] Luthans, Fred, Organizational Behavior. Ten editions. Yogyakarta: Andy. Offset, 2012

[10] Mariati, Influence of Organizational Communication to the Parliament Office Employee Job Satisfaction Sinjai. Thesis. Faculty of Da'wa and Communication Alauddin State Islamic University, Makassar, 2017

[11] Dr. Bishawjit Chandra Deb, Muhammad Shajib Rahman and Ishrat Jahan, An Analysis of the Levels of Employee Satisfaction: A Study on Janata Bank Limited. Journal of Management, 5(5), 2018, pp. 172-183.

[12] Marroli JI, Communication Management of Government Information Transparency Policy. Thesis. Jakarta: Social UI, 2012

[13] Novieka and A. Prasetya, Influence of Organizational Communication on Job Satisfaction and Organizational Commitment (Study on Employee PLN Pasuruan Area). Journal of Business Administration (JAB) Vol. 61 (4), 2018, pp 133-142.

[14] Pace, R. Wayne, Organizational Communication (Strategies Improve Corporate Performance). Bandung: Rosda, 2013

[15] Stingy, Elbeyi., Yuksel Ozturk., And sure Arslanturk, The effects of employee empowerment on employee job satisfaction A study on hotels in Turkey, 2011

[16] Robbins, Stephen P. and Timothy A. Judge, Organizational Behavior. Jakarta: Publisher Salemba Four, 2013

[17] Sanuja Shree P.N, Dr. S. Gurusamy and P. Balaji, Employee Satisfaction on Labor Welfare Measures: An Empirical Examination of Manufacturing Companies, International Journal of Production Technology and Management (IJPTM), 10(1), 2019, pp. 77-86.

[18] Suranto,For Effective Communication Support Office Performance. Yogyakarta: UNY, 2017

[19] Umar, H, Research Methods for Business Thesis and Thesis. Jakarta: King Grafindo Persada, 2011

[20] Waqas, A., Bashir, U., Sattar, MF, Abdullah, HM, Hussain, I., Anjum, W., Ali, MA, and Arshad, R., 2014. Factors Influencing Job Satisfaction and Its Impact on Job Loyalty, International Journal of Learning and Development, Vol. 4. No. 2. pp. 141-161.

[21] Wibowo, Performance Management Third Edition. Jakarta: Rajawali Pers, 2012 